\title{
二次元微小共振器レーザーにおける空間モードの選択励起
}

\author{
福嶋 丈浩1, 砂田哲 ${ }^{2}$ \\ '岡山県立大学情報工学部情報通信工学科 ( $7719-1197$ 岡山県総社市寉木111) \\ 2金沢大学 理工研究域機械工学系 (广920-1192 石川県金沢市角間町又7番地)
}

\section{Selective Excitation of Spatial Modes in Two-Dimensional Microcavity Lasers}

\author{
Takehiro FUKUSHIMA ${ }^{1}$ and Satoshi SUNADA ${ }^{2}$ \\ ${ }^{1}$ Department of Information and Communication Engineering, Okayama Prefectural University, 111 Kuboki, Soja, Okayama $719-1197$ \\ ${ }^{2}$ Faculty of Mechanical Engineering, Institute of Science and Engineering, Kanazawa University, Kakuma-machi, Kanazawa, \\ Ishikawa 920-1192
}

(Received February 13, 2015)

\begin{abstract}
Advances in fabrication technologies have allowed the fabrication of laser cavities with arbitrary 2-D shapes. 2-D cavities have a wide variety of spatial modes, which have different wavefunctions. From the viewpoints of both fundamental physics and practical applications, it is important to selectively excite one desired mode from among many spatial modes. In this paper, we review the methods of selective mode excitation for 2-D microcavity laser diodes based on the control of both cavity shape and electrode contact pattern. We also review two major applications of the selective excitation technique to fundamental research in both quantum and laser chaos. One is the observation of chaos-assisted tunneling, and the other is compact chaotic laser devices that consist of a 2-D microcavity laser and an external feedback cavity. Finally we refer to the potential applications of the selective excitation technique to such functional optical devices as beam-switching devices and polarization-switching devices.
\end{abstract}

Key Words: Two-dimensional cavity, Microcavity laser, Selective excitation, Spatial mode

\section{1.はじめに}

共振器に閉じ达められた光線の振舞は, 共振器の形状 に大きく依存する。例えば, 円盤形の共振器では, 光線 は同じ入射角を保ったまま端面で反射を繰り返す。ま た, 2つの曲面ミラーを対向させたファブリー・ペロー 型の安定共振器では, 共振器の軸に沿った周期軌道が幾 何学的に安定になるように共振器が設計される ${ }^{1)}$ 。これ らの共振器は古くから研究が行われており, 光線の振舞 を反映した共振器モードが形成されることが知られてい る。 円盤形の共振器では共振器の端に光が局在するウイ スパリングギャラリーモードが現れ，安定共振器条件の ファブリー・ペロー型共振器ではエルミート・ガウス モードが現れることが知られている ${ }^{1,2)}$. しかし, 周り が閉じた二次元微小共振器では，このような軌道のみな らず，しばしば不規則な振舞を示す軌道が現れる。この ようなカオス的な軌道を有する共振器(カオス共振器)に おいて, 光線軌道とモード (波動)には単純な対応関係が 成り立たないことが知られており, そのような共振器で レーザーを発振させた場合に得られる発振モードを調べ ることは, 興味深い研究課題である ${ }^{3,4)}$.
現在までに様々な形状の二次元微小共振器レーザーが 活発に研究されてきたが, 比較的早期の研究として, た とえば，1998年のベル研究所Capasso教授とイエール大 学Stone教授の共同研究グループによる蝶ネクタイレー ザーが有名である ${ }^{5)}$ 。この研究では, 共振器の形状を円 盤形から少しずつ歪ませた複数の量子カスケードレー ザーを製作して発振モードを系統的に調べている。その 結果, 共振器パラメータを適切に選ぶと, 従来両立する ことが困難であった高いQ值と指向性を同時に有する モードを励起できることを示し，注目を集めた。

同じ頃，スタンフォード大学Siegman教授の研究グ ループは，ファブリー・ペロー型共振器の片方の端面ミ ラーを曲面ミラーとし，さらに側面ミラーを設けた不安 定共振器条件の擬似スタジアム型 $\mathrm{GaAs}$ 半導体レーザー を製作して，光線軌道と発振モードの関係を調べ た ${ }^{6-8)}$. この研究では, 不安定な周期軌道に光が局在す る特殊なモードが現れることを実験と理論の両面から明 らかにしている。

本論文では，筆者らによる擬似スタジアム型半導体 レーザーに関する研究の展開として, 安定共振器条件の 擬似スタジアム型半導体レーザーにおいて特定の安定周 
期軌道に対応する空間モードを選択的に励起する方法を 紹介する。導波路を用いた一次元的な共振器と異なり， 面内に光を閉じ込める二次元共振器には多彩な空間モー ドが現れる。これらのモードの中から所望のモードを選 択的に励起する技術は，学術的な観点のみならず応用の 観点から見ても重要である。ささらに, 本方法をカオスの 研究に応用した例を紹介するとともに，ビームスイッチ 素子や偏光スイッチ素子をはじめとする光機能デバイス への応用の可能性について述べる.

\section{2. 空間モードの選択励起}

レーザーは，発振に寄与するモードに対して損失を補 うだけの利得を与えることで発振に至る ${ }^{1)}$. 二次元微小 共振器に現れる複数の空間モードの中から, 特定のモー ドを選択的に励起するには, 所望のモード以外の空間 モードの損失が大きくなるように設計するか, 所望の モードに対する利得を他の空間モードより高く設計する 必要がある。

例えば, Fig. 1に示すように二つの曲面ミラーを二つ の側面ミラーで繋いだ擬似スタジアム型共振器には, 軸 に沿った周期軌道, 菱形の周期軌道, 側面ミラーで複数 回反射を繰り返す菱形周期軌道, そして, カオス軌道が 存在する.このように比較的単純な形状であっても二次 元共振器には多彩な光線軌道が現れる。ここでは, Fig. 1 (a) と (b) に示した軸軌道と菱形軌道に対応する空 間モードをそれぞれ選択的に励起する方法を紹介す る $^{9-11)}$.

まず，側面ミラーで複数回反射する周期軌道 (Fig. 1 (c)) やカオス軌道 (Fig. 1 (d)) に対応する空間 モードを除去するためにFig. 2に示すように共振器の四 隅が開いた形状を採用する。四隅に光吸収領域を設けれ ば，ここに入射した光線軌道は発振に寄与しなくなる。

次に, 軸軌道と菱形軌道に対応するモードが形成され るためには, 共振器長 $L$ 曲面ミラーの曲率半径 $R$ が安 定共振器条件 $(L \leq 2 R)$ を満足するように設計する必要が ある ${ }^{1,12)}$. それぞれのモードの波動関数の空間分布は, 拡張Fox-Liモード計算法と呼ばれる反復計算法を用いる ことで求めることが可能である ${ }^{12)}$. 計算で得られた空間 分布に合わせて電極コンタクト領域を形成して電流を注 入すれば，所望のモードに高い利得を与えることが可能 になる。

Fig. 3は，それぞれ軸軌道モードと菱形軌道モードの 空間分布に合わせて電極を形成したGaAs微小共振器 レーザーの放射パターン (遠視野像)を測定した結果を示 している9，軸に沿って電極を設けたレーザーでは，軸 方向にビームが出力され，菱形の電極を設けたレーザー では, 菱形の周期軌道に対応する出射方向 $\left( \pm 19^{\circ}\right.$ の方 向)にビームが出力されている。しかしながら，ビーム の形状を見ると複数のピークが現れていることがわか る. 軸軌道モードと菱形軌道モードには, 横方向の光強 度分布に単一のピークを持つ最低次モードの他に, 複数 のピークを持つ高次モードが存在する ${ }^{12)}$. Fig. 3に示し

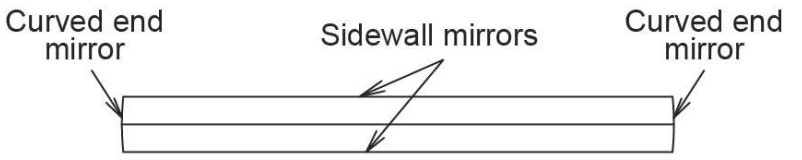

(a)

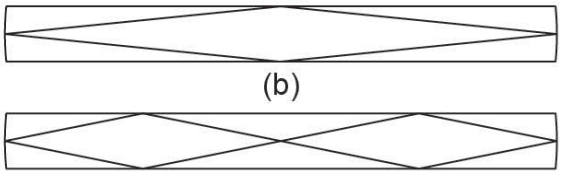

(c)

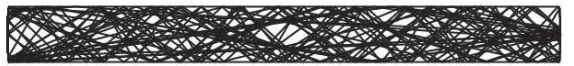

(d)

Fig. 1 Ray trajectories confined in a quasi-stadium cavity, (a) axial trajectory, (b) diamond-shaped trajectory, (c) diamond-shaped trajectory with multiple reflections at the sidewall mirrors, (d) chaotic ray trajectory.

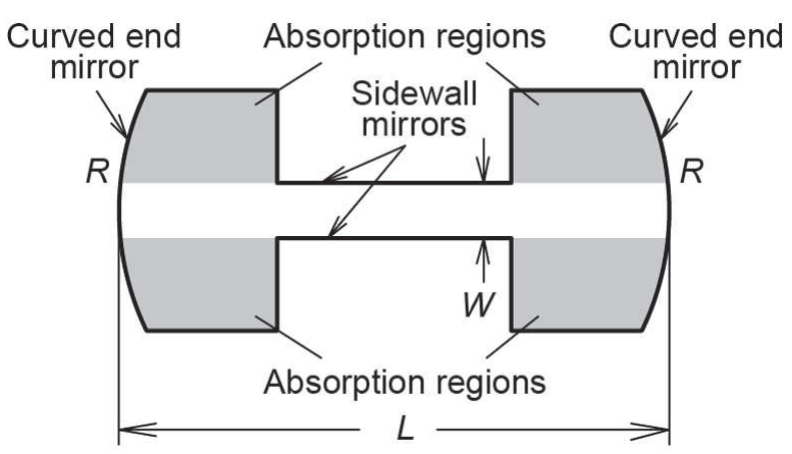

Fig. 2 Quasi-stadium open cavity with absorption regions (gray regions).

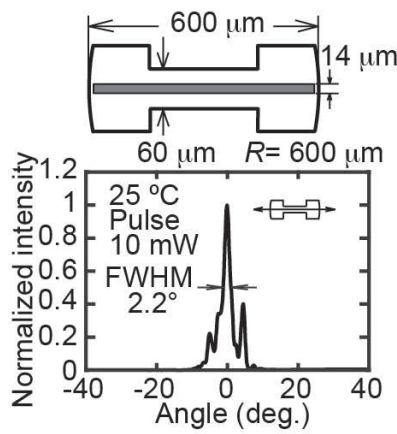

(a)

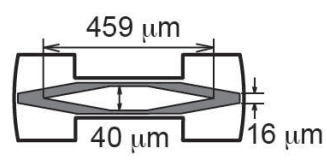

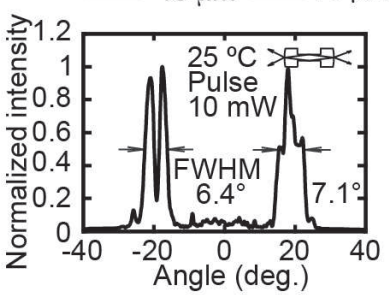

(b)
Fig. 3 Far field emission patterns of quasi-stadium laser diodes with an electrode contact pattern corresponding to (a) axial mode pattern and (b) diamond-shaped mode pattern.

た複数のピークは，最低次モードと高次モードが同時に 発振したことによって生じたと解釈されている9

次に, 高次モードの発振を抑えて最低次モードの発振 を得る方法について述べる。モードの次数が高くなる 程, 周期軌道に沿って伝搬するビームの幅が広くなる. したがって，電極コンタクトの幅を狭くして電流の拡が りを抑えれば，高次モードの利得を抑えることが可能に

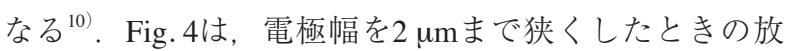
射パターンを示している. 高次モードの発振が抑制さ れ, 単峰性の出力ビームが得られている.

高次モードの発振を抑えるもう一つの有効な方法とし 


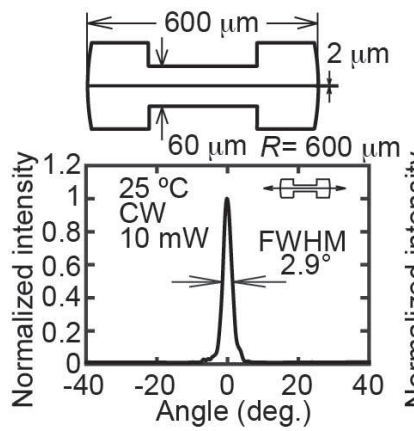

(a)
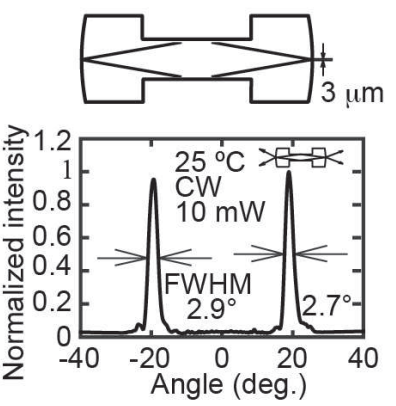

(b)
Fig. 4 Far field emission patterns of quasi-stadium laser diodes with a narrow (2- $\mu \mathrm{m}$ width) electrode contact pattern corresponding to (a) axial mode pattern and (b) diamond-shaped mode pattern.

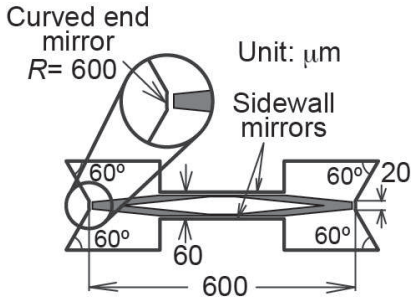

(a)

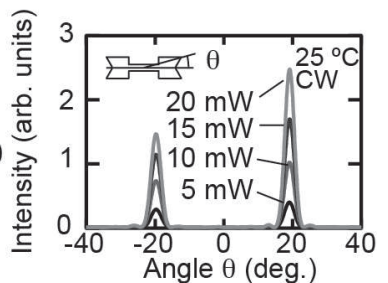

(b)
Fig. 5 (a) Schematic diagram of a quasi-stadium laser diode having narrow curved end mirrors and (b) far field emission patterns.

て，曲面ミラーの幅を狭くする方法が考えられる ${ }^{11)}$. 曲 面ミラーの幅を狭くすると，ビームの幅が広い高次モー ドは最低次モードに比べて大きな損失を受ける。 Fig. 5 は，菱形の電極を設けた擬似スタジアム型レーザーにお

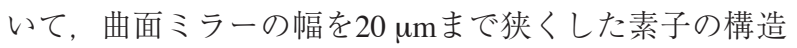
と放射パターンを示している. 光出力 $20 \mathrm{~mW}$ まて高次 モードの発振が抑えられ, 単峰性の出力ビームが得られ ている.

このように安定周期軌道に対応した空間モードについ ては, 共振器や電極の形状を工夫することにより, 選択 的に励起することが可能である. 一方, Fig. 1 (d) に示 したカオス軌道に対応する空間モードについては, 共振 器全体に光が分布するため選択励起が困難である. カオ ス軌道に対応するモードを励起するには, スタジアム型 共振器のように安定な周期軌道が存在しない共振器を用 いることが有効である ${ }^{13)}$.

\section{3. 量子カオス研究への応用}

古典力学におけるカオス現象が量子力学の系にどのよ うに刻印されるのかという問題を議論する物理学の一つ の分野に量子カオスと呼ばれる分野がある ${ }^{14)}$. 例えば, 箱の中に閉じ込められた古典的な粒子の運動を考える と, 粒子の軌道は箱の形に大きく依存する。粒子がカオ ス的な振舞を示すような箱において, 古典的な粒子がと る軌道とシュレディンガー方程式を解いて得られる波動 関数や固有值との関係を調べる研究が古くから行われて いる ${ }^{15)}$ 。ここで, 箱を光共振器に, 粒子の軌道を光線の
軌道に置き換えると，定常状態ではどちらも同じヘルム ホルツ方程式で記述される。このような類似性から, 量 子カオスの分野で明らかにされた理論的な研究成果を光 やマイクロ波の共振器で検証することが試みられてい る。本章では量子カオスの研究分野で興味が持たれてい るカオストンネル現象 (Chaos Assisted Tunneling)を選択 励起の技術を用いて検証した例を紹介する ${ }^{16,17)}$.

カオストンネル現象を観測するために考案された共振 器の形状と光線の軌道をFig. 6に示す.この共振器には, Fig. 6 (a)に示した四角形の周期軌道が存在する。この 周期軌道は幾何学的に安定であり, 光線が周期軌道から 僅かに逸れたとしても図のように光線は周期軌道から離 れることなく，四角形の軌道の周りを回り続ける。ま た，別の軌道として，Fig.6（b）に示したカオス軌道が 存在する. 四角形の周期軌道の周りを周回する光線とカ オス軌道は独立であり, 光伝搬を光線で考える限り, こ れらの軌道が結合することはない.しかし, 波動の伝搬 を考えた場合には，四角形の安定周期軌道の周りに局在 した光のエネルギーの一部がカオス軌道に流れることが 指摘されており, このような現象はカオストンネル現象 と呼ばれている。

このようなトンネル現象は，四角形の周期軌道に対応 する空間モードを選択的に励起して, 光の放射パターン を観測することで確認できる。半導体で共振器を製作す ると四角形の周期軌道に対応するモードは全反射で共振 器の内部に閉じ込められる。トンネル現象が起こらなけ れば, Fig.6 (a)に示した矢印のように反射点から接線 方向 (水平軸に対して $\pm 45^{\circ}$ と $\pm 135^{\circ}$ の方向)に微弱なエバ ネッセント波の放射が起こると予想される。一方，トン ネル現象が起これば，四角形の軌道に沿って伝搬する レーザー光の一部がカオス軌道へ結合することになる. この光は, 共振器内部に広がり, 全反射条件を破って方 向性のある放射を引き起こすと予想される。その結果, 全反射で高効率に光を閉じ込めつつも指向的な放射を伴 う，一見すると矛盾したような発振モードが得られると 考えられる. 実際, 四角形の軌道に対応する空間モード の波動関数を計算するとFig. 6 (b) に矢印で示すように 水平軸に対してェ90の方向にピークを持つ放射が生じ ることが示されている ${ }^{16)}$.

Fig.7に製作した微小共振器レーザーの素子構造と放

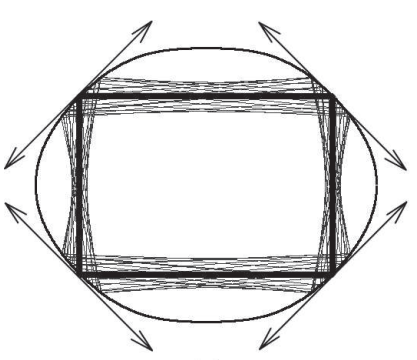

(a)

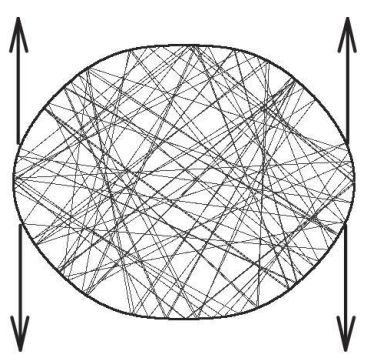

(b)
Fig. 6 Ray trajectories in a two-dimensional microcavity designed for observing chaos assisted directional emission, (a) stable periodic rectangle trajectory, (b) chaotic trajectory. 
射パターンの観測結果を示している. 四角形の周期軌道 に対応するモードに合わせて電極コンタクトが形成され ている，電流を注入するとレーザー発振が起こり, 光ス ペクトルに四角形軌道の軌道長に対応した等間隔のピー クが観測される ${ }^{17)}$ 。このことから, 四角形の軌道に対応 した空間モードが選択的に励起されていることが確認で きる，放射パターンには，Fig.7 (b) に示すようにカオ

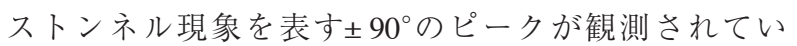
る16). これは, 抽象的な数理モデルに偏りがちな量子力 オスの理論研究を実在する半導体レーザーによる実験に 結び付けて理論予想を実証した数少ない例の一つであ $ろ^{18)}$.

\section{4.レーザーカオス信号生成素子への応用}

レーザーカオスの研究分野では, 半導体レーザーの出 力光に遅延を与えて再び共振器に戻すことによって高速 な不規則振動が現れることが古くから知られている ${ }^{19)}$. このような現象は, 戻り光カオスと呼ばれており, 過去 30年間に渡って研究が行われている。近年, このような 戻り光カオスを秘匿通信や物理乱数生成に応用する研究 が行われている ${ }^{20,21)}$. 実用化の観点から, カオス信号生 成素子の小型化が重要な課題になっており, 半導体レー ザーと外部共振器をモノリシックに製作した光集積デバ イスが提案されている22-26)，本章では，カオス信号生成 素子に空間モードの選択励起の技術を応用した例を紹介 する.

カオス信号生成素子の小型化を目的として, 分布帰還 型レーザーと直線導波路をモノリシックに製作した戻り 光カオス素子が提案されている22,23)。しかしながら, 広 帯域のカオス信号を生成するには戻り光に十分な遅延を 与える必要があり，素子長が約 $1 \mathrm{~cm}$ と長くなる問題が あった。 近年, 半導体レーザーと外部共振器に二次元微 小共振器を用いることで，素子サイズを $1 \mathrm{~mm} \times 1 \mathrm{~mm}$ 以 下に小型化したカオス生成素子が提案されている ${ }^{24)}$.

Fig. 8はこのカオス生成素子の構造を示している. 左 側の擬似スタジアム型レーザーは，曲面ミラーと平面ミ ラーで共振器が構成されており, 軸軌道に対応する空間 モードが選択的に励起されるように共振器のパラメータ と電極形状を設計している. 一方, 右側の外部共振器に も曲面ミラーと平面ミラーで共振器が構成される擬似久 タジアム型共振器を採用している。レーザーから外部共 振器に入射したビームが図に示した安定周期軌道に沿っ て伝搬して再びレーザーに帰還するように設計されてい る。外部共振器の長さは600 $\mu \mathrm{m}$ であるが, 外部共振器 に結合した光は共振器の中を6往復した後, レーザーに 戻るため，軌道の長さは約 $7.2 \mathrm{~mm}$ とな。このように 二次元微小共振器の内部に光路を折曲げて配置すること により短い共振器で長い光路長が実現できる.

レーザーを発振させて, 外部共振器の注入電流により 戻り光量を上げていくと, レーザーの出力光強度は, 時 間に対して安定な状態から不安定な状態へと移行する。 RFスペクトルを観測すると, 外部共振器の注入電流が

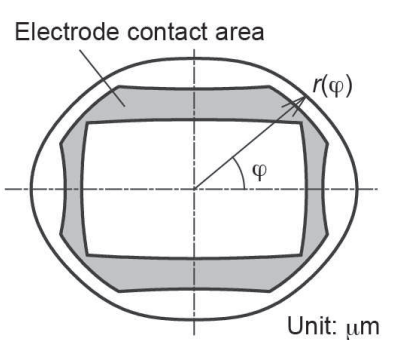

$r(\varphi)=50(1+0.1 \cos 2 \varphi+0.01 \cos 4 \varphi$ $+0.012 \cos 6 \varphi)$

(a)

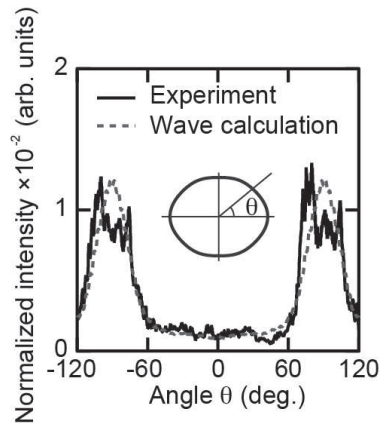

(b)

Fig. 7 (a) Schematic diagram of chaos assisted emission two-dimensional microcavity laser and (b) far field emission pattern.

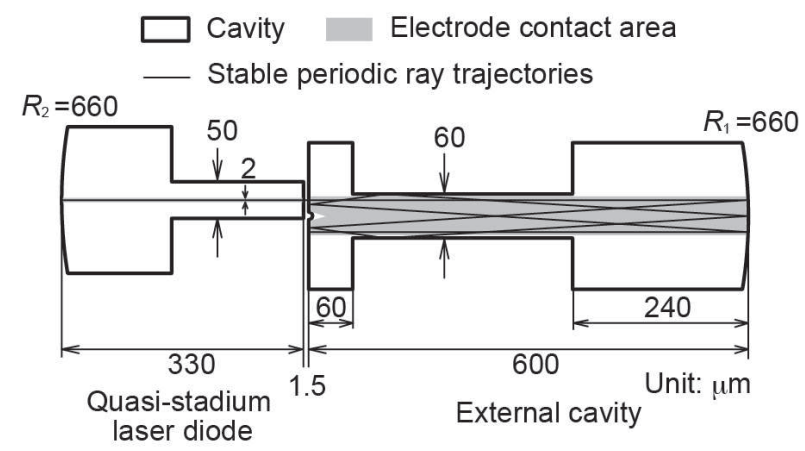

Fig. 8 Schematic diagram of a compact chaotic laser device with a two-dimensional external cavity.

ゼロの時は，緩和振動を表すブロードなピークが観測さ れる。この状態から外部共振器の注入電流を上げて行く と，RFスペクトルに鋭いピークが現れる，さらに電流 を上げると，ピークの強度が増加するとともに高調波の ピークが現れる，さらに，注入電流を上げるとピークの 幅が拡大して広帯域のカオス信号が観測される。このよ うなシナリオは, 外部共振器長に対応する周波数が半導 体レーザーの緩和振動周波数に比べて十分大きい場合に 見られるシナリオと良く似ており27)，理にかなった振舞 である。

Fig. 8に示した素子の設計において, 外部共振器に結 合した光は，端面で反射される度に共振器の外部に漏れ 出す。そのため, フィードバックの効率という観点から 見ると好ましい設計とは言えない.フィードバックの効 率を改善する一つの方法としてFig. 9に示す素子が提案 されている ${ }^{25,26)}$ 。この素子では，全反射を利用するため に外部共振器の形状を円形に近づけ，入出力ポートを設 けている。 入力ポートの端面から共振器に入射した光 は，全反射を繰返しながら星形の軌道に沿って共振器の 中を伝搬し，出力ポート端面に到達する。端面で反射し た光が再び同じ経路を辿ってレーザーに帰還する．星形 の光線軌道が幾何学的に安定になるように共振器の周辺 には，わずかな凹凸が設けられている。これまで外部共 振器の平均半径 $r_{0}$ が $100 \mu \mathrm{m}$ (往復軌道長 $3.72 \mathrm{~mm}$ ) と $150 \mu \mathrm{m}$ (往復軌道長 $5.58 \mathrm{~mm}$ )の共振器において星形の軌 道に沿って光が伝搬することが実験で確認されてい $ろ^{25,26)}$.

近年, 外部共振器長と生成されるカオス信号の関係が 
$\square$ Cavity Electrode contact area

_ Stable periodic ray trajectories

$r(\varphi)=r_{0}(1-0.005 \sin 13 \varphi)$

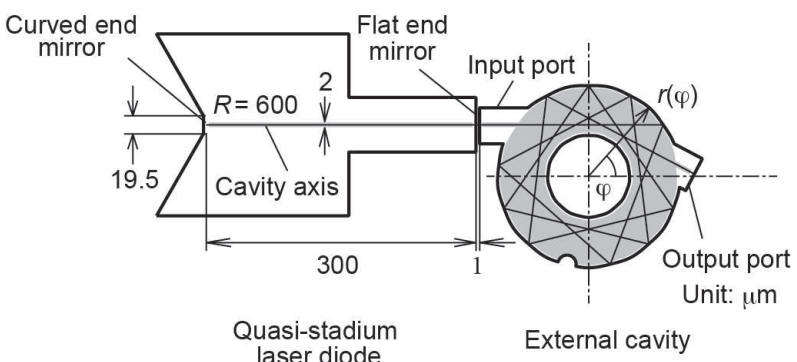

Fig. 9 Shematic diagram of an improved chaotic laser device with a two-dimensional external cavity.

詳しく調べられており, 往復遅延距離が $6 \mathrm{~mm}$ 以上とな る外部共振器で, 物理乱数生成に適した平坦で広帯域な スペクトルを持つカオス信号が生成されることが報告さ れている ${ }^{28)}$. 共振器の設計を最適化することで光路長を 延長することが今後の重要な課題である.

\section{5. 光機能デバイスへの応用の可能性}

二次元微小共振器の空間モードを選択的に励起する技 術が確立されると, 半導体レーザーに新しい機能を付加 することが可能になる。例えば, Fig. 2に示した擬似ス タジアム型共振器を有する微小共振器レーザーに軸軌道 と菱形軌道に沿った $2 つ の$ 電極を設けることで, 出力 ビームのスイッチ動作が可能になることが示されてい る29). しかしながら, この実験では共振器内部に小さな 光スポットが形成される共心型共振器条件 $(L=2 R)$ が用 いられている. そのため, 高出力動作においてビーム形 状の劣化が観測されている. Fig. 5に示すように共焦点 型共振器条件 $(L=R)$ を用いた実験では, $20 \mathrm{~mW}$ の光出 力まで単峰性の出力ビームが維持されている. 共振器と 電極の形状を最適化することで, 高出力動作に適した ビームスイッチ素子が可能になると予想される。

また，量子井戸構造を用いたレーザーでは，光学遷移 の選択則によりTEモードの利得がTMモードより高くな る. そのため, GaAs単一量子井戸構造を用いた二次元 微小共振器レーザーは, 通常, TEモードで発振する. 擬似スタジアム型微小共振器レーザーの軸軌道モードも TEモードで発振することを確認している。最近, 菱形 軌道の端面入射角をブリュースター角にほぼ一致するよ うに設計した微小共振器レーザーにおいて，TMモード の発振が得られることが報告されている ${ }^{30)}$ 。これは, 端 面入射角をゼロから大きくすると，TEモードの反射率 は，ブリュースター角に近づくにしたがって単調に減少 するのに対して，TMモードでは逆に反射率が増大する ため, TEモードのミラー損失がTMモードに比べて大き くなることが原因と考えられている。擬似スタジアム型 共振器を用いたビームスイッチ素子において菱形軌道の 端面入射角をブリュースター角に設定すれば, 光の出射 方向のみならず偏光モードのスイッチも可能になると考 えられる。
二次元微小共振器の空間モードを利用したビームス イッチ素子や偏光スイッチ素子は，選択励起技術の応用 例として大変興味深い.

\section{6. まとめ}

二次元微小共振器レーザーに現れる多彩な空間モード の中から特定のモードを選択的に励起する方法について 解説するとともに, 選択励起の技術を量子カオスやレー ザーカオスの研究に応用した例を紹介した。更に, ビー ムスイッチ素子や偏光スイッチ素子を始めとする光機能 デバイスへの応用の可能性について展望を述べた。空間 モードの選択励起技術は, 二次元微小共振器を利用した 新しいデバイス応用の可能性を切り開く重要な技術であ り，今後，応用を目指した研究が期待される。

\section{謝 辞}

二次元微小共振器レーザーの研究を共同で進めている NTTコミュニケーション科学基礎研究所の篠原 晋博士, 新井 賢一博士, 早稲田大学の原山 卓久教授に厚くお礼 申し上げます。また，研究を進める上でお世話になった 多くの方々に感謝致します。最後に，筆頭著者の福嶋 は, 二次元微小共振器レーザーの研究を始める機会をい ただいたスタンフォード大学の故Siegman教授に心より 感謝の意を表します。

\section{参考文献}

1) A. E. Siegman: Lasers (University Science Books, California, 1986).

2) S. L. McCall, A. F. J. Levi, R. E. Slusher, S. J. Pearton, and R. A. Logan: Appl. Phys. Lett. 60 (1992) 289.

3) T. Harayama and S. Shinohara: Laser \& Photon. Rev. 5 (2011) 247.

4) 福嶋 丈浩：電子情報通信学会誌 94 (2011) 323.

5) C. Gmachl, F. Capasso, E. E. Narimanov, J. U. Nöckel, A. D. Stone, J. Faist, D. L. Sivco, and A. Y. Cho: Science 280 (1998) 1556.

6) Y. Sun: Ph.D. thesis, Stanford University (1995).

7) T. Fukushima, S. A. Biellak, Y. Sun, C. G. Fanning, Y. Cheng, S. S. Wong, and A. E. Siegman: CLEO 1997 (1997) CWF6.

8) T. Fukushima, S. A. Biellak, Y. Sun, and A. E. Siegman: Opt. Express 2 (1998) 21.

9) T. Fukushima, T. Harayama, T. Miyasaka, and P. O. Vaccaro: J. Opt. Soc. Am. B 21 (2004) 935.

10) T. Fukushima, S. Sunada, T. Harayama, K. Sakaguchi, and Y. Tokuda: Appl. Opt. 51 (2012) 2515.

11) T. Fukushima, S. Shinohara, S. Sunada, T. Harayama, K. Arai, K. Sakaguchi, and Y. Tokuda: Opt. Lett. 38 (2013) 4158.

12) T. Fukushima: J. Lightwave Technol. 18 (2000) 2208.

13) S. Shinohara, T. Fukushima, and T. Harayama: Phys. Rev. A 77 (2008) 033807.

14）原山 卓久, 中村勝弘：量子カオス（倍風館, 2000).

15) M. C. Gutzwiller: Chaos in classical and quantum mechanics (Springer-Verlag, New York, 1990).

16) S. Shinohara, T. Harayama, T. Fukushima, M. Hentschel, T. Sasaki, and E. E. Narimanov: Phys. Rev. Lett. 104 (2010) 163902.

17) S. Shinohara, T. Harayama, T. Fukushima, M. Hentschel, S. Sunada, and E. E. Narimanov: Phys. Rev. A 83 (2011) 053837.

18) A. D. Stone: Nature 465 (2010) 696.

19) J. Ohtsubo: Semiconductor lasers (Springer Verlag, Berlin, 2006).

20) A. Argyris, D. Syvridis, L. Larger, V. Annovazzi-Lodi, P. Colet, I. 
Fischer, J. García-Ojalvo, C. R. Mirasso, L. Pesquera, and K. A. Shore: Nature 438 (2005) 343.

21) A. Uchida, K. Amano, M. Inoue, K. Hirano, S. Naito, H. Someya, I. Oowada, T. Kurashige, M. Shiki, S. Yoshimori, et al.: Nature Photon. 2 (2008) 728.

22) A. Argyris, M. Hamacher, K. E. Chlouverakis, A. Bogris, and D. Syvridis: Phys. Rev. Lett. 100 (2008) 194101.

23) T. Harayama, S. Sunada, K. Yoshimura, P. Davis, K. Tsuzuki, and A. Uchida: Phys. Rev. A 83 (2011) 031803.

24) S. Sunada, T. Fukushima, S. Shinohara, T. Harayama, K. Arai, and M. Adachi: Appl. Phys. Lett. 104 (2014) 241105.

25) S. Shinohara, S. Sunada, T. Fukushima, T. Harayama, K. Arai, K.
Yoshimura: Appl. Phys. Lett. 105 (2014) 151111.

26) T. Fukushima, S. Shinohara, S. Sunada, T. Harayama, K. Arai, K. Yoshimura, K. Sakaguchi, and Y. Tokuda: Frontiers in Optics 2014 (2014) JW3A.31.

27) T. Heil, I. Fischer, W. Elsäßer, B. Krauskopf, K. Green, and A. Gavrielides: Phys. Rev. E 67 (2003) 066214.

28) R. Takahashi, Y. Akizawa, A. Uchida, T. Harayama, K. Tsuzuki, S Sunada, K. Arai, K. Yoshimura, and P. Davis: Opt. Express 22 (2014) 11727.

29) T. Fukushima and T. Harayama: CLEO 2007 (2007) JWA127.

30) T. Fukushima, S. Shinohara, S. Sunada, T. Harayama, K. Sakaguchi, and Y. Tokuda: Opt. Express 22 (2014) 11912. 